\title{
The Oncological Emergency Case: Paraneoplastic Hypoglycemia in Metastatic Breast Cancer - Case Report and Brief Review of the Literature
}

\author{
Lisa Richters $^{a}$ Monika Ortmann ${ }^{c}$ Michael Faust ${ }^{d}$ Stefan Krämer $^{a}$ \\ Peter Mallmann ${ }^{a}$ Nadia Harbeck ${ }^{a, b}$ Kerstin Rhiem ${ }^{a}$
}

${ }^{a}$ Breast Center, Department of Obstetrics and Gynecology, University Hospital of Cologne, ${ }^{\mathrm{b}}$ Breast Center, Department of Obstetrics and Gynecology, University Hospital of Munich, Institute of Pathology, University of Cologne, ${ }^{\mathrm{d} C e n t e r ~ f o r ~ E n d o c r i n o l o g y, ~ D i a b e t e s ~ a n d ~ P r e v e n t i v e ~}$ Medicine, University Hospital of Cologne, Germany

\section{Keywords}

Hypoglycemia · Breast cancer · Metastases · Insulin-like growth factor - Paraneoplastic

\section{Summary}

Background: Paraneoplastic hypoglycemia is a rare syndrome amoung tumorous diseases. It is often associated with a paraneoplastic secretion of 'big' insulin-like growth factor-II. Methods: We describe this syndrome in a 60-year-old patient with advanced breast cancer 8 years after primary diagnosis. Results and Conclusion: This non-islet cell tumor-induced hypoglycemia may be the only evidence for an otherwise clinically occult disease progression. Fast diagnosis and appropriate acute and causal treatment concepts should be part of oncological management.

\section{Introduction}

Paraneoplastic hypoglycemia is a rare but severe complication in malignancies that was first described in 1930 by Doege in a case of mediastinal fibrosarcoma [1]. Since then, several cases of this adverse event have been described in combination with benign and malignant mesenchymal and epithelial neoplasms. The syndrome has only been described once in a patient with advanced breast cancer [2].

In most cases, hypoglycemia is due to a paraneoplastic secretion of 'big' insulin-like growth factor-II (IGF-II) [3, 4], a partially processed precursor of IGF-II. This abnormal IGF-II forms smaller complexes with IGF-binding proteins (IGFBPs) [5-7], and consecutively shows increased permeability and a higher bio-availability. Therefore, most patients with tumor-

\author{
Schlüsselwörter \\ Hypoglykämie · Brustkrebs · Metastasen · Insulin-like \\ Growth factor - Paraneoplasie
}

\section{Zusammenfassung}

Hintergrund: Die paraneoplastische Hypoglykämie ist ein seltenes Syndrom im Zusammenhang mit Tumorerkrankungen. Sie ist häufig mit einer paraneoplastischen Sekretion von "big»-Insulin-like Growth Factor-II (IGF-II) assoziiert. Methoden: Der vorliegende Fallbericht beschreibt das Syndrom bei einer 60-jährigen Patientin mit fortgeschrittenem Mammakarzinom 8 Jahre nach Erstdiagnose. Ergebnisse und Schlussfolgerung: Die Nicht-Insellzelltumor-induzierte paraneoplastische Hypoglykämie (NICTH) kann ein Hinweis auf einen bisher nicht diagnostizierten Tumorprogress sein. Die Diagnosestellung sowie die adäquate Akut- und Kausaltherapie gehören ins Repertoire des Onkologen.

induced hypoglycemia exhibit IGF-II concentrations within normal ranges.

The production of IGF-I and IGFBP-3 is reduced as a consequence of negative feedback induced by growth hormone $(\mathrm{GH})$. This results in a higher concentration of free IGF-II, and in an elevated IGF-II to IGF-I ratio, which can be used as diagnostic tool for paraneoplastic hypoglycemia (reviewed in [8]).

This paraneoplasm is distinct from insulin-induced hypoglycemias (observed, for example, in insulinomas), and has been termed non-islet cell tumor-induced hypoglycemia (NICTH). Although this complication is very rare, especially in gynecological malignancies, it is a severe metabolic emergency, potentially leading to hypoglycemic coma. Hence, a fast diagnosis and effective treatment are essential.

\section{KARGER}

Fax +497614520714

Information@Karger.com

www.karger.com (c) 2013 S. Karger GmbH, Freiburg

$1661-3791 / 13 / 0085-0368 \$ 38.00 / 0$

Accessible online at:

www.karger.com/brc
PD Dr. med Kerstin Rhiem

Klinik und Poliklinik für Frauenheilkunde und Geburtshilfe Uniklinik Köln

Kerpener Str. 34, 50931 Cologne, Germany

Kerstin.Rhiem@uk-koeln.de 


\section{Case Report}

In June 2001, a 52-year-old woman presented with a mass in her left breast and involvement of the left axillary lymph nodes. The right side was unsuspicious. A core needle biopsy showed a moderately differentiated ductulo-lobular breast cancer with positive hormone receptor status. Staging investigations, including x-ray of the chest, abdominal sonography and bone scintigraphy, demonstrated bone metastases, while the parenchymal organs were without pathological findings. The patient received an aromatase inhibitor (anastrozole) and a bisphosphonate (clodronate) as palliative treatment.

In March 2002, pleural and pulmonary metastases were diagnosed and chemotherapy with paclitaxel and mitoxantrone was initiated, leading to partial remission. In September 2002, the patient underwent breast conserving surgery of the left side with axillary lymph node sampling and mastopexy on the right side (stage: ypT3 ypN2 cM1 G2).

After surgery, the endocrine therapy was switched to letrozole and clodronate until July 2006. At this point, progression of bone metastases and recurrence of pleural metastases were detected, and therapy with fulvestrant and clodronate was initiated. Since July 2007, the patient has been given several therapy regimens, including capecitabine followed by exemestane, liposomal doxorubicin and docetaxel, resulting in partial remission. The remaining pulmonary metastases were treated by palliative radiation until July 2009. Maintenance therapy with anastrozole was then started and switched to letrozole because of negative side effects. The patient subsequently developed skin metastases on her back and antihormonal therapy with fulvestrant was re-initiated in August 2009.

In October 2009, the patient was admitted to our clinic in a pre-comatose state. Laboratory analysis showed a severe hypoglycemia with a plasma-glucose level of $9 \mathrm{mg} / \mathrm{dl}$. Administration of glucose promptly ameliorated the patient's state. She regained consciousness, was fully orientated and did not present with any neurological deficiencies. To rule out intracranial sources of her loss of consciousness, a cranial CT (computed tomography) was performed. The scan did not reveal signs of intracranial bleeding or brain metastases.

Further laboratory testing exhibited significantly decreased levels of IGF-I, IGFBP-3, insulin and C-peptide, whereas IGF-II levels were low but within the normal range (table 1). This led to a pathological IGF-II to IGF-I ratio of $>>14$ (normal: $<0$ [2]) and a suspected diagnosis of a paraneoplastic hypoglycemia. Further investigations, including ultrasound of the liver and blood tumor marker (CA 15-3 > 3,000 kU/l, normal range $<25 \mathrm{kU} / \mathrm{l}$ ), were carried out and showed a massive hepatic progression, thereby substantiating our hypothesis. Under symptomatic treatment with constant infusion of glucose $(20 \%, 100 \mathrm{ml} / \mathrm{h})$, dexamethasone $(4 \mathrm{mg} /$ day) and somatostatine (100 $\mu \mathrm{g} / \mathrm{day})$, the patient was without symptoms for several days.

The only known effective treatment of paraneoplastic hypoglycemia is the reduction of tumor mass. In this case of disseminated breast cancer, surgical treatment was not indicated so that we planned another palliative

Table 1. Overview of all relevant laboratory analysis at admission of the patient according to their reference parameters

\begin{tabular}{lll}
\hline Parameter & Value & Reference range \\
\hline Glucose, mg/dl & 9 & $55-115$ \\
CA15-3, kU/1 & $>3000$ & $<25$ \\
Insulin, mU/ & 5.41 & $6-29.1$ \\
Peptide-C, $\mu$ g/l & $<<0.1$ & $0.9-7.1$ \\
HbA1c, \% & 4.91 & $4.8-6.0$ \\
IGF-I, $\mu$ g/l & $<<25.0$ & $81-225$ \\
IGF-BP3, mg/l & $<<0.5$ & $3.4-6.9$ \\
IGF-II, $\mathrm{ng} / \mathrm{ml}$ & 372 & $370-900$ \\
\hline
\end{tabular}

$\mathrm{Hb}=$ hemoglobin, IGF = insulin-like growth factor,

$\mathrm{BP}=$ binding protein chemotherapy. To our regret, patient's state worsened due to the massive progression and she died 11 days after referral.

\section{Discussion}

Although breast cancer is the most common malignancy in women in the western hemisphere, paraneoplastic hypoglycemia is a very rare syndrome in breast cancer and gynecological oncology [2,9-11]. Until now only 8 cases have been reported in the scientific literature, and to the best of our knowledge this is the second report on an NICTH in a breast cancer patient [2] (see table 2).

Hypoglycemia is a well-known emergency in clinical routine, mostly due to diabetes medication. As a complication in malignancies, it is commonly described as overproduction of insulin (by insulinomas or ectopic insulin-producing tumors) or as being caused by hepatic or adrenal cancerous destruction. Paraneoplastic hypoglycemia is usually induced by a huge tumor mass either of a primary tumor or an advanced malignancy. Therefore, paraneoplastic hypoglycemia could be the first manifestation of tumor progression or lead to the primary diagnosis of a so-far unknown neoplasm.

NICTH is typically caused by an inadequate production of insulin or IGF and IGFBPs. Ectopic secretion of an incompletely processed IGF-II by the tumor ('big' IGF-II) acts as an IGF with high bio-availability for IGF and insulin receptors and causes hypoglycemia [12]. In NICTH, insulin secretion is suppressed, resulting in low insulin and C-peptide levels. As negative feedback, high IGF activity restrains GH secretion, leading to reduced IGF-I and IGFBP-3 production in the liver [13], as shown in the presented patient (table 1).

Intravenous glucose administration is the essential treatment for severe and persistent hypoglycemia. Hoff et al. [14] described infusion of glucagon as another treatment option. Application of glucocorticoids seems to be promising by correcting the GH-IGF axis, stimulating gluconeogenesis and, in some cases, suppressing the production of 'big' IGF-II. Moreover, glucocorticoids, GH or combination thereof could also inhibit NICTH and reduce associated symptoms [15]. The use of somatostatine analogues is a controversial issue. Chung et

Table 2. Summary of all cases of NICTH in gynecological disease published in international journals

\begin{tabular}{lll}
\hline Tumor entities with NICTH & Reference & Number of cases \\
\hline Phyllodes tumor of the breast & & \\
Unknown status & {$[18,19]$} & 2 \\
Benign & {$[20,21]$} & 2 \\
Malignant & {$[22]$} & 1 \\
Metastasized breast cancer & {$[2]$} & 1 \\
Fibrous tumor of the uterus & {$[23]$} & 1 \\
Ovarian cancer & {$[24]$} & 1 \\
\hline NICTH = non-islet cell tumor-induced hypoglycemia &
\end{tabular}


al. [16] observed a reduction of 'big' IGF-II secretion evoked by continuous somatostatine infusion. Another author reported that octreotid did not restore glucose levels [17].

Removal or cytotoxic reduction of the 'big' IGF-II-producing tumor is the only causal therapy. Through an increase in individualized therapeutic options (e.g. small molecules, antibodies) the survival of patients in advanced tumor stages will improve. Therefore, diagnosis and treatment of this oncological emergency case may be more common in future.

\section{Acknowledgement}

The authors are indebted to the patient without whose generous permission this report would not have been possible. We thank Fabian Kütting for his critical linguistic review of the manuscript

\section{Disclosure Statement}

The authors declare no conflict of interests.

\section{References}

1 Doege KW: Fibro-sarcoma of the mediastinum. Ann surg 1930;92:955-960.

2 Bessell EM, Selby C, Ellis IO: Severe hypoglycaemia caused by raised insulin-like growth factor II in disseminated breast cancer. J clin pathol 1999;52: 780-781.

3 Marks V, Teale JD: Tumours producing hypoglycaemia. Diabetes Metab Rev 1991;7:79-91.

4 Service FJ: Hypoglycemic disorders. N Engl J Med 1995:332:1144-1152.

5 Daughaday WH, Kapadia M: Significance of abnormal serum binding of insulin-like growth factor II in the development of hypoglycemia in patients with non-islet-cell tumors. Proc Natl Acad Sci USA 1989;86:6778-6782.

6 Zapf J, Futo E, Peter M, Froesch ER: Can 'big' insulin-like growth factor II in serum of tumor patients account for the development of extrapancreatic tumor hypoglycemia? J Clin Invest 1992; 90:2574-2584.

7 Zapf J, Schmid C, Guler HP, Waldvogel M, Hauri C, Futo E, Hossenlopp P, Binoux M, Froesch ER: Regulation of binding proteins for insulin-like growth factors (IGF) in humans. Increased expression of IGF binding protein 2 during IGF I treatment of healthy adults and in patients with extrapancreatic tumor hypoglycemia. J Clin Invest 1990;86:952-961.

8 de Groot JW, Rikhof B, van Doorn J, Bilo HJ, Alleman MA, Honkoop AH, van der Graaf WT: Non-islet cell tumour-induced hypoglycaemia: A review of the literature including two new cases. Endocr Relat Cancer 2007;14:979-993.
9 Daughaday WH: Hypoglycemia in patients with non-islet cell tumors. Endocrinol Metab Clin North Am 1989;18:91-101.

10 Daughaday WH, Emanuele MA, Brooks MH, Barbato AL, Kapadia M, Rotwein P: Synthesis and secretion of insulin-like growth factor II by a leiomyosarcoma with associated hypoglycemia. $\mathrm{N}$ Engl J Med 1988;319:1434-1440.

11 Le Roith D: Tumor-induced hypoglycemia. N Engl J Med 1999:341:757-758.

12 Morbois-Trabut L, Maillot F, De Widerspach-Thor A, Lamisse F, Couet C: 'Big IGF- II'-induced hypoglycemia secondary to gastric adenocarcinoma. Diabetes Metab 2004;30:276-279.

13 Jones JI, Clemmons DR: Insulin-like growth factors and their binding proteins: biological actions. Endocr Rev 1995;16:3-34

14 Hoff AO, Vassilopoulou-Sellin R: The role of glucagon administration in the diagnosis and treatment of patients with tumor hypoglycemia. Cancer 1998;82:1585-1592.

15 Drake WM, Miraki F, Siddiqi A, Yateman M, Barnes NC, Camacho-Hübner C, Monson JP: Dose-related effects of growth hormone on IGF-I and IGF-binding protein-3 levels in non-islet cell tumour hypoglycaemia. Eur J Endocrinol 1998; 139:532-536.

16 Chung J, Henry RR: Mechanisms of tumor-induced hypoglycemia with intra-abdominal hemangiopericytoma. J Clin Endocrinol Metab 1996;81:919-925.

17 Perros P, Simpson J, Innes JA, Teale JD, McKnight JA: Non-islet cell tumour-associated hypoglycaemia: 111In-octreotide imaging and efficacy of octreotide, growth hormone and glucocorticosteroids. Clin Endocrinol (Oxf) 1996;44:727-731.
18 Aguiar Bujanda D, Rivero Vera JC, Cabrera Suarez MA, Aguiar Morales J, Christol R, Bohn Sarmiento U, Dominguez Cabrera C, Le Bouc Y: Hypoglycemic coma secondary to big insulin-like growth factor II secretion by a giant phyllodes tumor of the breast. Breast J 2007; 13:189-191.

19 Herr M, Chung MH, Belnap C,Person DA: Residents' case series: Insulin-secreting cystosarcoma phyllodes of the breast: A case report and literature review. Hawaii Med J 2004;63:211-213.

20 Hino N, Nakagawa Y, Ikushima Y, Yoshida M, Tsuyuguchi M: A case of a giant phyllodes tumor of the breast with hypoglycemia caused by highmolecular-weight insulin-like growth factor II. Breast Cancer 2010;17:142-145.

-21 Li TC, Reed CE, Stubenbord WT Jr, Ettinghausen S, Peterson CM, Jovanovic L, Poffenbarger PL: Surgical cure of hypoglycemia associated with cystosarcoma phyllodes and elevated nonsuppressible insulin-like protein. Am J Med 1983;74:1080-1084.

22 Kataoka T, Haruta R, Goto T, Sugino K, Asahara T, Dohi K, Kaneco M, Arihiro K, Nomura S: Malignant phyllodes tumor of the breast with hypoglycemia: Report of a case. Jpn J Clin Oncol 1998; 28:276-280.

23 Wakami K, Tateyama H, Kawashima H, Matsuno T, Kamiya Y, Jin-No Y, Kimura G, Eimoto T: Solitary fibrous tumor of the uterus producing highmolecular-weight insulin-like growth factor II and associated with hypoglycemia. Int J Gynecol Pathol 2005;24:79-84.

24 O`Neill RT, Mikuta JJ: Hypoglycemia associated with serous cystadenocarcinoma of the ovary. Obstet Gynecol 1970;35:287-289. 